\title{
Interpretation of the Practical Significance of the Peasant Theme in Contemporary Chinese Oil Painting
}

\author{
Yuanming Zhang \\ Zhuhai College of Jilin University \\ Zhuhai, China
}

\begin{abstract}
At present, when the country is influenced by the city, the farmers, who are the majority of Chinese society, are in a position of being ignored. The large amount of the key function in the society development have certified their importance, who is an important part but ignored by us, which can be found from their current living environment and condition.
\end{abstract}

Keywords-mission of the times; reflect reality; humanistic concern; criticize; chance

\section{INTRODUCTION}

In the 1980s, the Chinese artists began to independently and deeply think the social culture after they experience the "red, light, bright" and the "high, big, full" era. The painted farmer images reflect the concept and social attitudes of the artists and they express their observation and understanding to the farmers' problems by their own way. The artists feel their lost and apathy, but thankfully, also warmth and longing, they reserve the grave of life and the individual dignity. In the view of history, it isn't important that the artists believe in what kind of faiths but make good work, while, to make the good work based on the strong thinking support and mental strength behind. Without the spiritual support, the art will failure. The painted figure likes a mirror which reflects the artists' heart, and brings them to think the current city state and their own mental state.

\section{THE NECESSARY AND PROBABILITY TO TAKE FARMER AS THE OIL PAINTING THEME}

After 1990s, more and more famers' images are displayed in the oil painting, they are simple or optimistic or thinking; the spiritual outlook and the reality living environment and the social status of them can't help making us think the living environment of the "famer" - one disadvantage group ignored by the society. At present, the concept of farmer means the one who work in the city and their family members, farm at home or live in the village but do small business for life, workers in township enterprises and agricultural machinery. At present, when the country is influenced by the city, the farmers, who are the majority of Chinese society, are in a position of being ignored. The large amount of the key function in the society development have certified their importance, but it is an important part but ignored by us that their current living environment and condition.
The Chinese artists began to independently and deeply think the social culture after they experience the "red, light, bright" and the "high, big, full" era. With the deepening of the reform, the artists get rid of the bondage of the traditional administrative framework, no longer need to play the narrator of any political discourse. The self-expression way, form innovation and the conceptualization has become as the art mainstream one after another, the real and vivid image of the current famers created by the artists presents to the canvas. The happy and helpless status of the figures on the canvas, did wework hardly for life-experience it, didn't us? As a matter of fact, when we painted the farmers, we actually painted ourselves. Artists put their personal observation and understanding on the problem of the contemporary peasant into the image of the farmers. Emphasizing the critical position in spiritual exploration, emphasizing the painter's humanistic care and social responsibility, which is the essence of neorealism, and also indispensable to any era.

\section{The PRACTICAL SignificANCE OF THE PEASANT THEME IN THE CONTEMPORARY OIL PAINTING}

\section{A. Social Responsibility, the Mission of the Times}

In the context of the rapid development of the whole society, the quality of life, social status, living environment, cultural literacy and other aspects of the famers have been far behind, which needs the attention of the artist. The contemporary Chinese oil painting has the responsibility to proceed from the reality, create a truly touching outstanding works, and reflect the problems in our time and the better pursuit and yearning. The farmers' subject of the oil paintings of the contemporary artists are concerned with the actual living conditions of peasants, some of them are the subjective depictions of the typical characters in typical environments, some of them show the ancient relics which have long been unfamiliar to us and are about to be forgotten. The contents of the paintings reflect the artists' care about the national spirit state, traceability and identification of the national culture, thinking about the historical era under the modern market economy, and make deep study and discussion to the future development of China's social and cultural direction.

New artists represents such as Xiaodong Liu, Dongwang Xin, Yanzhao Zhang, Weixin Xu and so on are working hard. (Dongwang Xin) "We should give an account of history, and let our future generations also perceive that we have had such a 
state. If the pale, hypocritical, whitewashed works are left to the history, I'll feel ashamed." 1 Artists not only paint the peasants, but paint for the peasants, we can feel the great changes of the times through the most richly expressive people in the society. The phenomenon of migrant workers is a typical reflection of the expression of the times, in addition to factors of the screen itself, bearing the responsibility to reflect the times and social criticism is the charm and value of artistic works. Weixin $\mathrm{Xu}$ "It is the artist's duty to reflect the real life of society, to reflect the spirit of the times, to influence people, to teach people, and to resonate with others in your art." 2 The peasant subject is the field that Chinese contemporary oil painting should intervene and must intervene.

\section{B. Reflect the Reality, Cause Attention}

1) Attention to the living state of the peasants: Dongwang Xin's works in 2006 "Winter" shows the most common daily state of life of the ordinary people of the most common class Depicts the two farmers from suburbs of Beijing, unkempt old $\mathrm{He}$, whose land is being commercialized, makes his life by buying recyclers and sale the small specialty products. He is modernized dress, but does not seem to be really modernized. The swarthy skin and face wrinkles with typical life props make it easy to think of their living conditions, and make the people to pay attention the real life from the material and spiritual level.

2) Reveal the social status and the cultural identity changes of farmers: Economic development accelerated the process of agricultural modernization, and the status of peasants returned to the real state from the previous "mainstream". In order not to be left behind in the times, can live a good life, they hope to break through cultural identity and social status. There is a similar description in Dongwang Xin's own works "Fashionable": Due to the situation, the young woman coming to Beijing from Inner Mongolia works as modeling while singing. In this unfamiliar environment, the contrast caused by the ideal and the reality formed a cynical psychology. New purchased clothes, in fact, is the banner that she used to remind her not losing her own direction, demonstrate her identity and alert her pursuit. It is can be felt the contempt to the young woman from the middle-aged woman's eyes standing next to her. The passing of the youth and middle-aged situation make her secretly hide a low selfesteem. Corresponding to the middle-aged women are full of contradictions in the psychological, her slightly fat body fierce collide against the fashionable clothing. Although there is disdain expression staying out of her eyebrow, but empty eyes can't conceal the inner yield. As woman, they know much about the cruel behind the bustling city. Trying to be fashion is the instinct response of them. It displays the inadaptation phenomenon of the famers due to the environment change in the urbanization process after "being fast urbanization".

3) Reflect the farmers' ideology: In "Rural Election", work of Yanzhao Zhang, the smile from the simple and honest image makes us feel much: the Social is in progress, farmers can finally participate in the grass-roots elections, such a simple smile can really understand the mean of the election to them? Can their actions affect the outcome of the election? Is the political indifference or greatly awakening after the calm? The work provides us the possibility to think much.

\section{Reflect the Care of Humanity}

The peasants, in the real life, are controlled by various forces, they become as the vulnerable groups in the society, and thus they need the help and concern of all circles of the society. As the art workers, we need to use our pictures to express the concern of humanity.

The current society is undergoing great changes: the traditional values are challenged caused by the rapid economic growth and interwoven of the social conflicts. As the art workers with a sensitive nerve and social insight must have their own thinking to the society and will be reflected in their works. Pingxiang Deng evaluates in the "Villages Biography" exhibition that "he (Dongwang Xin) depicts the real status of human beings under his nib, his exhibition gives us a lot of inspiration in the absence of a visual sense of the artist's time." 3

Socio-economic prosperity and the reality of being completely commercialized have left many artists insulated from the peasant community. The spirit of some artists and the pursuit of art form both surpass the current social reality of thinking \& lack of guidelines to their own real life. A large number of art works take the subjects that reflect the city "petty bourgeoisie" life and development. With the rise of "return" wave, there are some artists aware of the farmers in the present society is a group needed an urgent concern, they contribute tremendous energy to the social progress, but they do not keep up with the wave of progress. Due to the concern for human nature, in the pictures of Xiaodong Liu, Dongwang Xin who is the representative of the artists appeared more farmers' image. Different from the past, the image of the peasant in the contemporary artists embodies the humanistic care and social responsibility of the artists. The peasants in the picture exist in the real social background to reveal the current situation of peasants' subsistence. Farmers yearn for the city, not because of avoiding labor or hating land, they want to gain the existence dignity in society when they have incomes from the land. "Good days" only exists in the city. The fate of the soil is always at the bottom of society. Although they are never willing to eat, but the personally planted fresh fruit is always picked for the sake, leaving only the growing hope to the fruit trees and bankers after hard work. Their work does not need to have benefits \& no more pensions; the community can only give them meager surplus profits. Greater harvest than the one of land makes them leave their homes; the community also ignited their mind to break away the hard life when it extracted their surplus. Women also came to the city, they do not appear in the construction site like men, almost all the hard service industry is their shelter, inexperienced girls are swaying with the times and growing accompanied by the times. They thought the life will be very happy after leaving land, but the fact is that they, shuttling in the reinforced concrete jungle, have to accept the test of survival when they experience the bustling of the city. Of course, the society is in progress, the 
farmers' life have been improved a lot in the aspect of material point. Artists can understand the people, know the society and also know themselves. In the process of social evolution, each of us, including painters themselves are playing the role of farmers, aren't we? In fact, the painter is not only painting the peasants but also painting himself. Only then the artist can really feel the peasantry from the heart and depict the peasants. The image of the farmer in the painter's expression expresses the artist's own concept and social attitude and seeks his own expression to express the observation and understanding of the current peasant's problem. The peasants in the picture are no longer praised and praised, but the figures with their own thoughts and ways of life in real life. It is more fortunate is that although the artists feel the loss and indifference, as well as warmth and vision in their sense. The artist retains the solemnity of life and respect for the individual, which embodies the artist's concern for the human nature of the farmers.

Weixin Xu's oil painting has also concerned about human contradictions and tragedy. His works "Work for Others" make people heartache after reading; though the hard-working, practical and in full swing worked farmers are wearing a stained mud stained old clothes, the spirit of them is still optimistic. His "Miners" series make people feel shocked. It is this pain deeply touched the audience, aroused our sympathy for workers, our attention to the real life \&the living environment of the migrant workers make us know more about them and help them.

Dongwang Xin, in his work "Bare M", said: "When a man come to the end of the child's naked, what can make him once again calmly exposed." Spiritual contradictions can be imagined, survival reality makes they dare to face the traditional moral concept of psychological embankment. In the name of art which is regarded as a career, but for men in life is undoubtedly a helpless choice .Facing the model, My nib not only touched the respect to the human body painting, but also tried to feel the naked struggle in their body that occupied position in the process of social transformation, and then had nothing at all, and naked for surviving as the son, husband and father."4

In Dongwang Xin's work "Breakfast" let us have a sense of inexplicable moved, moved in this indomitable and local conditions adjusting life atmosphere, moved in people's practical look in the impetuous society. Brilliant food culture is one of the reasons for the extremely extravagant and moral decline after being used by the corrupt elements with the greed heart. But the majority of people living in the bottom of society can't leisurely enjoy the changes brought by the food culture; they can only feel the hardships of life and the delight for winning the food. Once upon a time, we ourselves have the same situation as them, and make us feel quite deep: different from the heroic, real and chic psychological feelings of the people in the grand hotel, people who eat in the street stalls always hide a kind of psychology, do not want others to see their frugal state, but had no choice but endured the peep of the passers-by, so most of them will leave immediately after finishing the meal to try to return to the dignified and calm state as soon as possible. In any case they enjoy their breakfast very well at here. Then the new day begins, everyone is full of enthusiasm and hopes to feel the sunshine and meet the challenges, and all this psychology has been passed to every cell through the organs during the dishes impact sound.

In the historical perspective, it may not be important that what kind of faith kept by the artists, but paint very well is important. The factor for painting well is the strong ideological support and spiritual willpower behind the painting, the skills without the ideological support just like the army without command; do not know fight for whom. Without the spirit support, the art will be failure also. And the strong spiritual support is the artist's concern for human nature.

\section{Criticizes and Introspects to the Present Urban Condition}

At present, the cost of living in urban areas is gradually increased, and social competition is intense, the interpersonal relationship is cold and the trust of society is rapidly declined, people's eyes is filled with material, just like being placed in the mighty ocean and easy to be lost. The peasants' image under the painter often lets us get back the lost heart. We seem to find the happiness of life when we feel their optimism, we seem to find the happiness when we feel their hard work, and our lost seemed pale by comparing with their living environment. The characters in the painting just like a mirror which directly reflects our hearts, and causing us to think the current state of the city and our own mental state.

Xiaodong Liu has always been concerned about and depict the ordinary people and migrant workers depict the city, directly describe the city people do not care under the spirit of the lack and confusion after bored, "Burn Mouse" "Hotbed" are more typical works. Dongwang Xin's description of a primitive state of innocence may be a criticism and reflection of the contemporary urban state. The impetuous life of the city makes us forget the human nature of the innocent and open mind. The peasants in Yanzhao Zhang's life live in a livelier and free world space, perhaps they are relatively poor in material, but their spirit is given unlimited freedom and expansion. We seem to feel the author standing among the farmers, telling the viewer that he is a farmer, I said is that their village that something! Poverty and hardships in the eyes of the city may be their source of leisure and happiness, they have been vented by those who drown the city cannot understand the small happiness.

From Yanzhao Zhang's works "The Village", "Home Story" we can feel his profound, simple, mellow feelings to his hometown and the farmers living at the bottom of the society: Sweat and sun put the plateau red to the dark face of the women, men \& children, the red nose of the uncle lived in the village is given by the sunshine color and is the certificate given by life; it is the desire of each of us that the unfettered children and the relaxing spirit displayed on the adults face. There seems hide the subtle little cunning after the innocent smile on the laughing face, which make us truly feel their joy and happiness, as well as open-minded attitude to life. The small details of these make people cannot help laughing and feel happy. The same parts between he and the peasants are clearly displayed on the canvas, thought there is still "cold" and "loss", it cannot deny the lives of their lives. The painters feel the "warmth", "longing", "hope" and "happiness" from the 
peasants at the same time, it is the adjustment of our body and mind to enjoy the good works and feel their artistic concept, there is infinite extension included in this limiting canvas. Painters have had a similar description, they asked their heart when they feel confused, the home atmosphere and childhood mind spread -beautiful wind and beautiful scene, groups of men and women temporarily not be completely eroded and covered by the city's hubbub . They are ordinary, they live and work naturally, and hardships brought by the life and ages, but they still reveals the non-decorative elegance. This is a group of nameless people and nameless fate, but perhaps they are the most direct and concrete manifestation of human destiny.

\section{E. Creates a Broad Creative Space and Opportunities}

The peasant theme also provides the Chinese contemporary oil painter with a broader artistic space and creative opportunity. Due to the different perspectives and approaches of the peasantry, the perspectives and the starting points of the artists' involvement in the peasant theme works, and the expression techniques also have their own characteristics. Some vigorous mellow, some angular, and some emphasize ink mood. Diligent, brave, simple, optimistic image of the farmers infected us, but also provide the unlimited possibilities for creation of artists.

In the form of language, contemporary oil paintings with peasant theme most adopt the concrete realism. The artists more directly and broadly portrayed in the real world, and most of them do not delicately express the surface of the object, oil painting and weak the ideal color in painting oil. Momentary trigger the potential spirit and the natural life characteristics with oil paint and brush or scraper. Pursuit the wonder of nature of the oil painting, the picture is lively. The artists not only paint the living object but also skillfully use the oil paint, brush and scraper, which are means do not halt the so-called shaping and characterization. Pursuit the integrity of the image icon, weaken the sensitive contrast, interpret the body's logic by color. This is suitable for the brave, hardworking, simple performance of farmers, and some artists understand and express the image form from the perspective of freehand to achieve the perfect combination of form and content, do sustained and deep research to the oil painting on the nationalization and localization aspect.

Yanzhao Zhang's painting adopts the Chinese "inkpainting" technique in oil painting, uses the oil as the ink when he is painting. The local color is thin and transparent; the canvas texture has become one part of the picture language. The spirit of Chinese freehand brushwork blend with the exquisite oil painting shows the strong vitality. In order to create a unique sense of the old adobe in "Honest City" and "Tomorrow, Cloudy to Sunny", works of Dongwang Xin, the author uses a rough picture texture, simple brown gray tone, round with the body structure, large scraper form of the wide strokes to express it. It is just like the wiped all by the peasant workers; the beauty of the oil painting material itself is fully used, and also makes the form and content with the perfect combination, which enhance the performance of realistic oil painting.
It is beneficial and even successful that make the oil painting nationalization based on the peasant theme. And also provide more performance techniques for the oil painting with farmers theme. We can not illustrate the two cultures is truly combined through the integration of some techniques, but this attempt and exploration of the development of contemporary Chinese oil painting has a very important significance.

\section{CONCLUSION}

In such a pluralistic era, the broad and diverse subject matter of the artists is the embodiment and endowment of the present multi-era. The development of the times gives us a relaxed and comfortable artistic atmosphere, and the peasants who make indelible contributions to the development of our times do not have chance to experience the things belongs to them. The artists have the responsibility and obligation to pay attention to them, and cause concern of the whole community to their large crowd. Whether the artistic works can express the human spirit and soul and cause people's thinking and sentiment determine the height of the art. The contemporary oil painter should start from the point of mind perception and social concern to show more peasant theme to reflect the ultimate concern of truth, kindness and beautify. Farmers are not selfish, they are kind, simple and optimistic, like a mirror always reflecting our hearts; let us find their direction in the troubled world and spiritual home. Meanwhile, the oil painting with the famers theme provides multiple possibilities of creation for the artists. The artists depict themselves while they paint others, the refraction of the works can be more pure the soul of the audience who reading the oil painting. It has a very positive significance to concern on the peasants theme for artist's individual and the whole society.

\section{REFERENCES}

[1] Changjiang Zhou Leading editor: "oil painter studio report portrait interpretation" Shanghai calligraphy and painting press 2004.

[2] "Dongwang Xin. Class lecture for oil painting portrait" Tianjin people's arts publishing house 2004.

[3] Dejiang Jia: "Dongwang Xin. New realism oil painting" Beijing craft arts publishing house 2003 .

[4] Ge Chao: "Sensitive-the narrator of a intellectuals painter ",Life.Read. new knowledge Sanlian bookstore, edit of Nov.200.

[5] Xuguang Chen: "Why art" Chinese renmin university press, edit of Jan.2004.

[6] Kandinsky[Russia]: "Discussion on the art spirit", Chinese social and science press, Jul., 1987.

[7] Hongjian Wang: "An introduction to art", Culture and art press, edit of Jan. 2000. 